\title{
Determination of Temperature-Moisture Relationship by Linear Regression Models on Masonry and Floor, Kruja, Albania
}

\author{
Klodjan A. Xhexhi, Andrea Maliqari, and Paul L. Meunier
}

\begin{abstract}
Kruja is a middle range city located in the center of Albania. The city of Kruja dates back to its existence from the V-VI century and extends to the city around the VI and IX centuries. It becomes the first capital of Albania in the XI-th century, specifically in 1190. This paper is going to deal with only two groups of buildings which are an integral part of the historical city of Kruja, the historical dwellings (XVIII century) and socialist ones (1960-1985). The aim of this paper is to analyze through linear regressions the relation between two parameters: moisture content and temperature of the indoor walls and floors of the historic and socialist buildings in the city of Kruja. Three types of historic dwelling and three types of socialist apartments have been analyzed, relatively uniformly oriented. The measurements with specific instruments are done in the same day, during three hours. The degree of reactivity is different for both groups of buildings. The historical buildings are more sensitive to temperature rise. They respond invers to it (as the temperature rise, the level of the moisture content decreases), with a higher coefficient than socialist ones and appear to be more efficient in reducing the level of the moisture, despite the average moisture content is higher. This paper takes into consideration also the analyze of the materials of the construction for both categories. If the level of the moisture is reduced, the buildings will be improved and the quality of life indicators of the inhabitance will be improved too.
\end{abstract}

Index Terms-Building Materials, Linear Regression Models, Moisture Content, Temperature.

\section{INTRODUCTION}

\section{A. Background}

Sustainable design of building concentrate mainly on three area including: energy performance, environmental impact, and inhabitants' safety and health [1]. Dealing with this issue, the interior of the dwellings should be more isolated from the exterior environment. Taking precautions in relation to the humidity levels in the buildings is necessary.

Moisture problems are so common in buildings, many of us consider them inevitable. Controlling moisture is important to protect occupants from adverse health effects and to protect the building, its mechanical systems and its contents from physical or chemical damage. Moisture

\footnotetext{
Published on April 14, 2020.

K. A. Xhexhi is with the Faculty of Architecture and Urbanism, Polytechnic University of Tirana, Albania (e-mail: klodjanxhexhi@yahoo.com)

A. Maliqari is with the Polytechnic University of Tirana, Albania (email: amaliqari@yahoo.fr)

P. L. Meunier is with Estp, Paris, France (e-mail: plmeunier@wanadoo.fr)
}

causes problems for building owners, maintenance personnel and occupants. Many common moisture problems can be traced to poor decisions in design, construction or maintenance. Moisture control is adequate as long as vulnerable materials are kept dry enough to avoid problems. The buildings must be designed, constructed and operated so that the materials do not get wet, or to manage them to dry quickly in case they get wet.

Prolonged moisture conditions can lead to colonization of mold, bacteria and insect of building materials. Various reactions with building materials can lead to corrosion process in metals and failure of the bonding elements of tiles and roofs. Water-soluble materials can be problematic. Wooden materials can swell or rot. Bricks or concrete can be damaged during freezing cycles and by depositing salt under the surface. Paint and plaster can be damaged and thermal resistance (R-value) can be reduced [2]. On the other hand, the moisture content of the wall has a direct impact on the thermal resistance of the walls. This is due to the increase of thermal conductivity value of the wall [3].

With the rise of the temperature, the construction elements expand or contract. These changes of temperature may act uniformly on these elements but under normal climatic conditions, the temperature gradient set up within the elements is usually nonlinear and the inducted internal stress can be significant. Just as masonry materials are subject to expansion due to an increase in temperature, they are also subject to shrinkage as moisture is lost [4].

The historical buildings in the inner citadel of Kruja, in comparison with socialist buildings are composed with different building materials, consequently the relationship between moisture content and temperature variation will be different.

The purpose of this paper is to analyze the relationship between temperature and moisture content in walls and floors, composed of different materials, through linear regressions models for historical and socialist dwellings.

\section{B. Literature review}

Increased moisture is one of the most common problems encountered in building structures. The control of the home's moisture exchange is important to determine the level of hygienic environmental conditions. The environment of indoor moisture is closely linked to health problems and also affects the sustainability of the construction and energy consumption [5]. Controlling the level of the moisture is important, this fact has become a global impact issue and construction practices are also constantly changing in relation to the issue [6]. High humidity level means bad smell in the inner dwelling, 
presence of mold, appearance of dust spiders and bacteria [7] [8]. In these cases, thermal bridges are created and relative humidity in the environment can be very high. Indoor humidity can cause condensation when the outside temperature is low enough to cause the development of thermal bridges [9].

Meanwhile the dry air makes the furniture shrink and crack. This post will cause skin irritation and difficulty breathing [5]. In these cases, the air quality will decrease and breathing problems will occur [8].

It is important to maintain air quality in the home in order to ensure constant comfort and durability. For this reason, the humidity and temperature levels must be maintained in accordance with the comfort parameters. There are several ways to control the humidity level in the building, one of them may be air conditioning system, which turns out to be very expensive [10]. Interior moisture in the home has also become a global issue, with its negative effects on building materials [11]. There is a higher probability of mold growth on masonry surfaces where the humidity level is $78 \%$ for wooden walls and $89 \%$ for concrete walls [12]. The windows, doors, walls which are in direct contact with the outside are the main areas where condensation may occur.

Maintaining optimal thermal conditions in the home is critical to the residents' physical comfort [13]. Poor thermal living conditions pose a high risk to health issues [14].

In order to benefit from the comfort thermal conditions in the dwelling, to protect the health of residents and improve their quality of life, it is necessary to maintain a proper temperature and humidity level of the interior of the dwelling [15].

The mold, mildew and condensation problems are either related to low surface temperature, high interior humidity levels or some combination of both. Understanding which factor dominates, a building low surface temperature or high vapor pressure, will limit the choice of effective strategies. In a leaky poor insulated home in a heating climate which is suffering from mold and mildew, is found a very high natural air exchange that dilutes interior airborne moisture and therefore maintaining a very low interior vapor pressure. Installing a fan in order to control the interior mold and mildew will not be effective since the interior moisture levels are already low. Meanwhile increasing the temperature of the surface by insulating the exterior wall, thereby reducing surface relative humidity would be a better strategy to control mold and mildew [18].

Wall moisture contents are often measured with some type of meter, but it is difficult to establish an exploitable relationship between moisture content and some measurable property of the material [19].

The consequence of long-term moisture, usually combined with excessive salinity, is the severe and extensive destruction of wall components. Before renovating specialized test of moisture content should be executed. In historical cities non-destruction methods are applied to measure the moisture content in brick walls. The destructed method is not accepted by the monumental protection authorities. Therefore, in these cities the electric methods should be used. The non-destructive methods provide an opportunity to conduct research in any number of measuring points. It is therefore very important to locate them in order to get the moisture profiles of a tested partition along its height, the length of a wall, along the perimeter of walls and also at different levels [20].

The historical buildings of Kruja are located in the archeological site "A" where is allowed restoration and conservation of monuments [21]. Meanwhile for the socialist buildings there is no policy of conservation.

In H.Radhi and S. Sharples study, a simple regression model was developed, based on the outcome of simulation. Three classes were used to construct the models: future climate data; current housing stock and energy consumption data of Abu Dhabi. This model considers the increase in air temperature, building thermal design, schedule of operation and the convection factor of fuel. The primary analyze was based on ordinary least square regression. This regression allows to analyze a dependent variable (such as cooling energy requirements, electricity, consumption of $\mathrm{CO} 2$ emissions) subject to various independent variables, such as air temperature, building design or working hours. The aim of the study was to promote the green materials and to improve the energy consumption and $\mathrm{CO} 2$ emission data [23].

M. Idraganti used a linear regression model based on the field studies. He integrated various environmental, behavioral, and psychological adaption, forming the bases for sustainable thermal comfort standards. The importance of occupant's adaptive behavior in achieving thermal comfort is highlighted [24].

B. Zhang1 and Z.Lei found through regression models the relationship through temperature and moisture variations characteristics of sintered clay and sand lime brick along the centerline. The IBM SPSS Statistics22 used for linear regression analysis, indicated that there was a negative correlation between the temperature and moisture content in the upper/lower part, for clay brick and sand lime brick with different values [25].

\section{Existing situation, historic and socialist buildings}

Historic buildings are located in the inner citadel of Kruja. The socialist buildings are mainly concentrated in the center of the city. All of these buildings date back to different periods of time. This detail is important in judging the evolution of the city over time and the coexistence between these groups.

The historic buildings are positioned inside the historic castle. Some of the buildings in the inner citadel are inhabited and abandoned, meanwhile some of them are reconstructed and built on the old ruins of the castle after the great fire that engulfed the castle in XVIII century. 


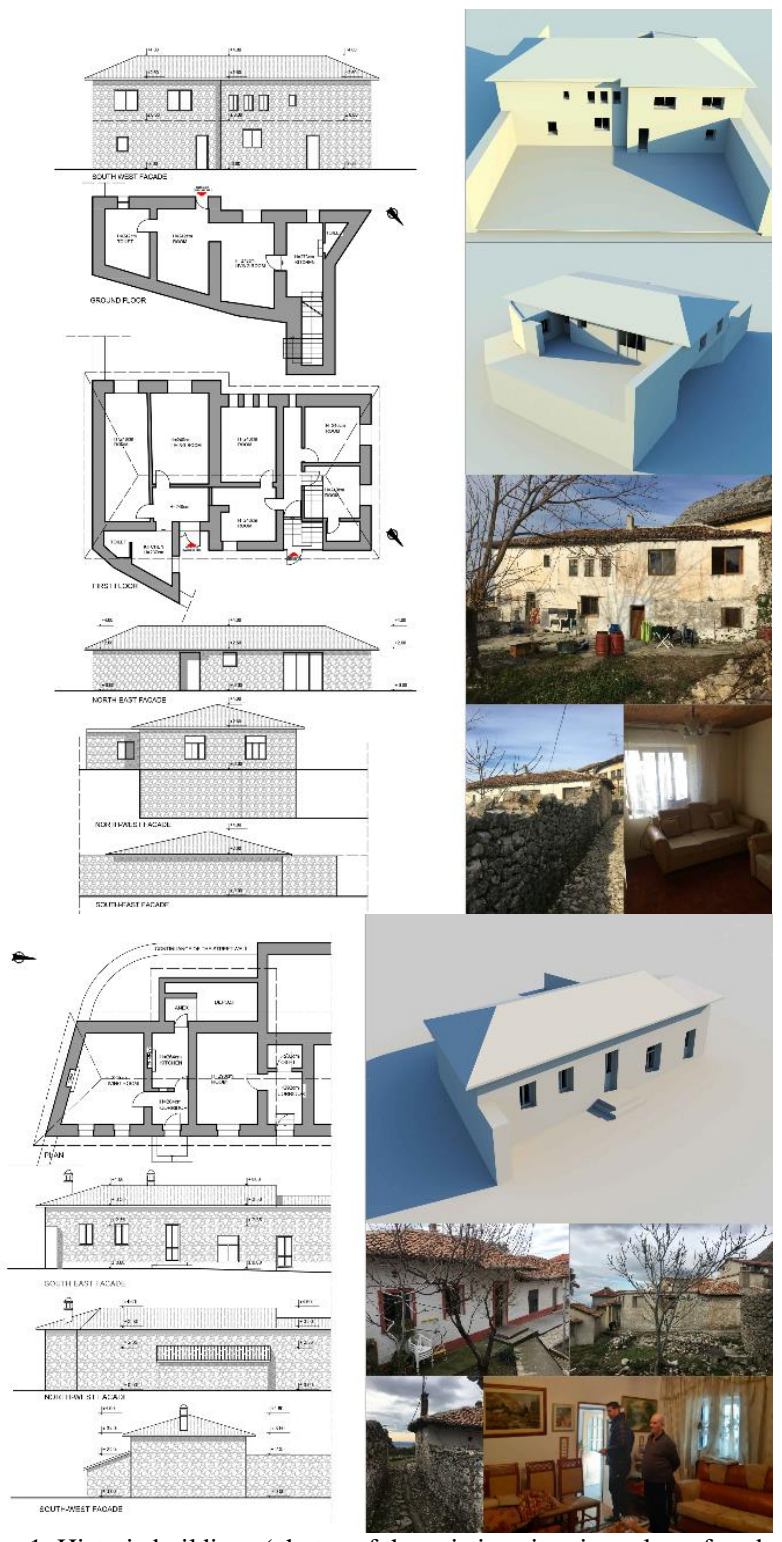

Fig. 1. Historic buildings (photos of the existing situation, plans, facades, 3d models); source: K.Xhexhi
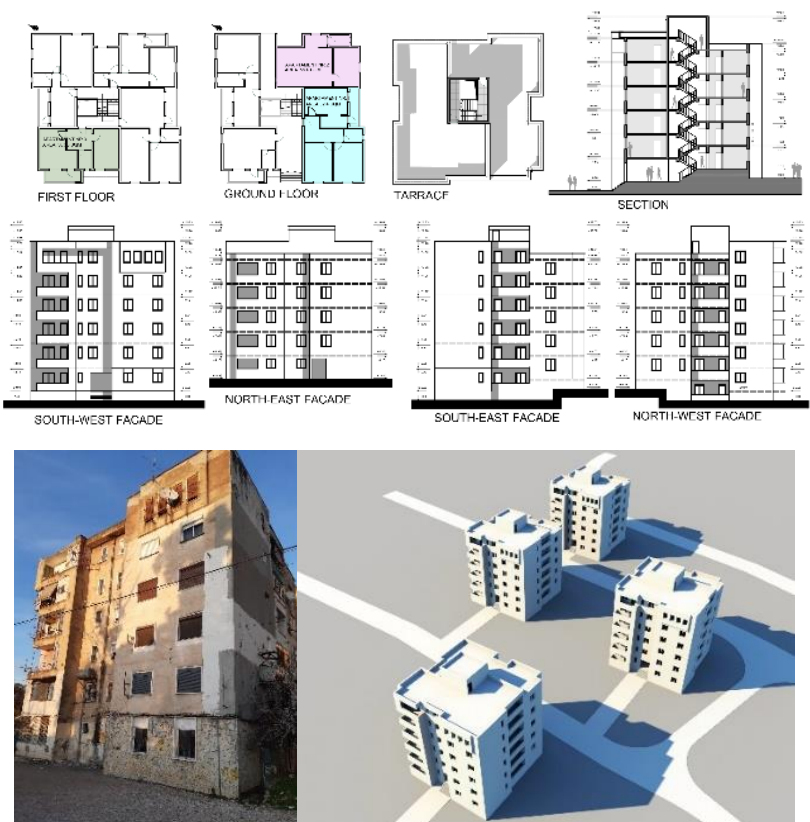

Fig. 2. Socialist buildings (photos of the existing situation, plans, section, facades, $3 \mathrm{~d}$ model of the group of buildings); source: K.Xhexhi
Socialist buildings date back to the second half of the XX-th century, around 1944-1990. These buildings of the socialist era are scattered throughout the city. The apartments that are considered were built during the 1960-s and 1985-s and are located relatively close to the city center. The flats analyzed in this study are the colored one, shown in plan (Fig. 2).

\section{INSTRUMENTS AND MEASUREMENTS}

Measurements were made only in the group of historic dwellings and the in the group of socialist dwellings. Three historic dwellings and 3 socialist apartments have been selected to carry out the measurements. The dwellings have been selected in order to have more or less the same orientation and also the same elevation development. The measurements were made on 26.01.2020 between the time band 11.00-13.00.

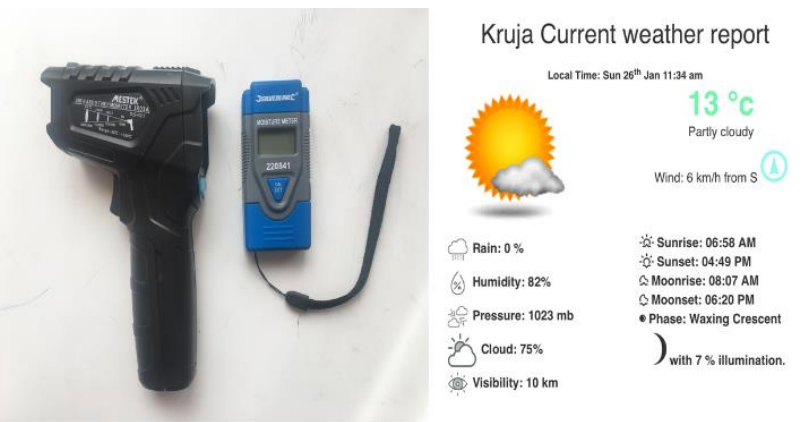

Fig. 3. A. Instrument of measurements; Temperature meter, Moisture meter; B. Kruja's weather report on 26.01.2020

Kruja's weather report (Fig. 1b) including outside temperatures of $13^{\circ} \mathrm{C}$, partly cloudy $75 \%$, humidity $82 \%$, and $10 \mathrm{~km}$ visibility, based on "World weather online" is shown in Fig. 3b. The instruments that have been used specifically for the measurement are shown in Fig. $3 \mathrm{a}$.

The moisture meter, (Silverline, Moisture meter 220841). The moisture meters are used to measure the percentage of water (moisture content) in a given substance.

The instrument has a margin of error of $+/-2 \%$ and measures moisture content in masonry and various building materials, tiles, concrete, wood, plaster etc. Measurements with this instrument are carried out only on the inner part of the interior walls and not on the outer part of the wall, with a frequency every $2-3 \mathrm{~m}$ for each wall as well as in the center of the floor for each room. The elevation of the measurements is $30-50 \mathrm{~cm}$. The unit of measure is expressed in $\%$. With the help of the pins of the instrument the surface of the walls and the floor is drilled in order to get the most accurate results. Maximum measurement is $60 \%$ (Fig. 1a).

Temperature meter (Mestek, Infrared Thermometer IROIA). This meter has an error margin of $0.1-1^{\circ} \mathrm{C}$. It measures the temperature in a range of $-50^{\circ} \mathrm{C}$ to $+380^{\circ} \mathrm{C}$ on different surfaces. The ratio of the distance to the measured point 12/1. Equipment response time is 0.5 seconds. This meter is used to measure both the facade as well as the temperature of the interior walls and temperature of the center of the floor for each room. The measurements of the floor are done without carpets or other floor coverings, directly in the tiles, wooden parquet or concrete floor and the measurements of the interior walls are done directly in 
the wall surface, relatively in the same vertical position with the moisture measurements. The elevation of the measurements is $50-150 \mathrm{~cm}$ from the level of the floor. The unit of measure is expressed in $\left({ }^{\circ} \mathrm{C}\right)$. The measurements are done also in the center of the windows but this study will not consider them. The study will take into consideration only the measurements of the temperature that are done on the inner part of the interior walls and in the center of the floor for each room (Fig. 1a).

\section{A. Moisture and building materials}

The ability to assess moisture contents and identify sources of moisture is of considerable importance in the conservation of historic buildings [19].

The average level of moisture content in the historic buildings is $21.21 \%$ from 66 observations and the average moisture content for the socialist buildings is $15.5 \%$ from 55 observations (Table I). Both categories are lack of relevant insulations, as a consequence it is normal that the level of the moisture is higher in historical dwellings. This category of buildings is more tied with the sloppy terrain and more degraded. Measurements have been made in two socialist apartments on the ground floor and one other apartment on the first floor, while for the socialist dwellings one apartment turns out to be developed on two levels, while the other two are 1-storey buildings, in direct contact with the ground. It is important to note that in some areas the moisture content exceeds $60 \%$ of the maximum measurement of the instrument, this applies only to historic buildings.

The exterior walls which are in direct contact with outdoor environment for historic buildings, are composed of natural stone (originating from the area) bonded with mortar between them. These walls vary in size from $65-75 \mathrm{~cm}$ plastered on both sides or in some cases partially plastered. They are in direct contact with the natural soil. The lack of appropriate insulations is very evident. The thickness of the plaster varies from $2-4 \mathrm{~cm}$ (Fig. $5 \mathrm{~b} ; 8 \mathrm{a}$ ). In some cases, concrete pavement was added to minimize the contact area between the natural soil and the perimeter walls of the dwelling (Fig.5d). Meanwhile the indoor partition walls vary from $20-30-45-55-75 \mathrm{~cm}$ for all three housing units.

Some partition walls, especially on the upper floors of the dwelling, turn out to be composed of a wooden structure with wooden beams interconnected between them, filled with construction material such as dry or inert mortar, and closed on both sides with wooden slats, separated from each-another by $2-3 \mathrm{~cm}$ and plastered with $2-4 \mathrm{~cm}$ of mortar on both sides of wall (Fig.4a).

Generally, the roofs are made of wooden trusts and covered with ceramic tiles (Fig. 5a; c). The slabs on the ground floors (for historic buildings), turn out to be filled with concrete, meanwhile the slabs in the second level appear to be composed of main wooden beams, secondary wooden beams + natural wooden parquet in the upper part (Fig. 4b; d). The bottom cover of the slab is realized either with rods connected by thin wire spacers $+2-3 \mathrm{~cm}$ plaster or in wooden decorative ceiling (Fig. 4c; d). The thickness of the wooden slabs varies between $35-40 \mathrm{~cm}$ (Fig. $4 \mathrm{~b}$ ).
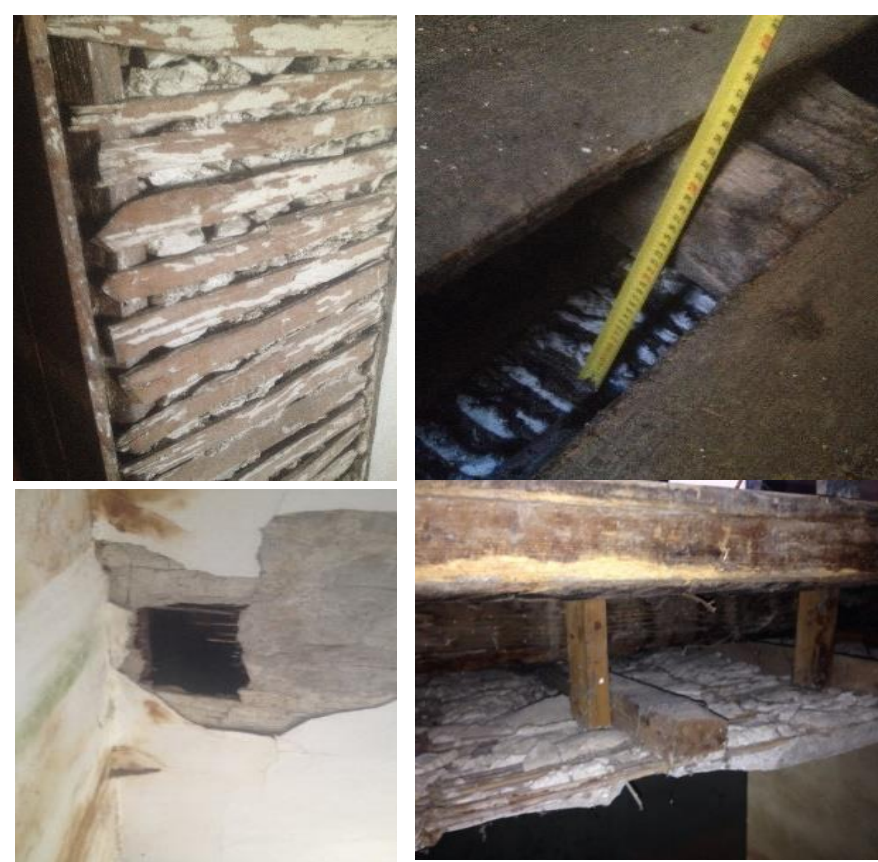

Fig. 4. A. Wooden indoor partition wall; B. Wooden slab; C. Bottom cover of the wooden slab; D. Section of the wooden slab Source: K.Xhexhi

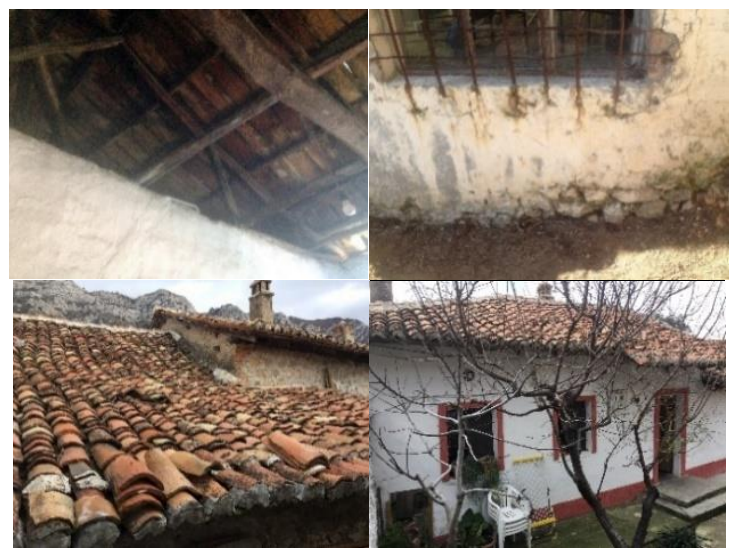

Fig. 5. A. Wooden roof; B. Outer stone wall; C. Ceramic tiles of the roof; D. Concrete pavement connected to the ground floor Source: K.Xhexhi

Meanwhile the socialist buildings have a combined structure of reinforced concrete, columns-slabs-beams (Fig. 6b) and partitions walls are made of silicate bricks $24 \times 12 \times 8 \mathrm{~cm}$ connected to each other with mortar and plastered on both sides (Fig. 6c; d). The exterior plaster has a granular composition in order to protected the building by atmospheric agents. Meanwhile the interior plaster is made of river sand mixed with cement. The ground floors are equipped partially with natural stone coatings. There is no waterproofing protection with surrounding terrain (Fig. 6a; $7 \mathrm{a} ; 7 \mathrm{~b} ; 8 \mathrm{~b})$. 


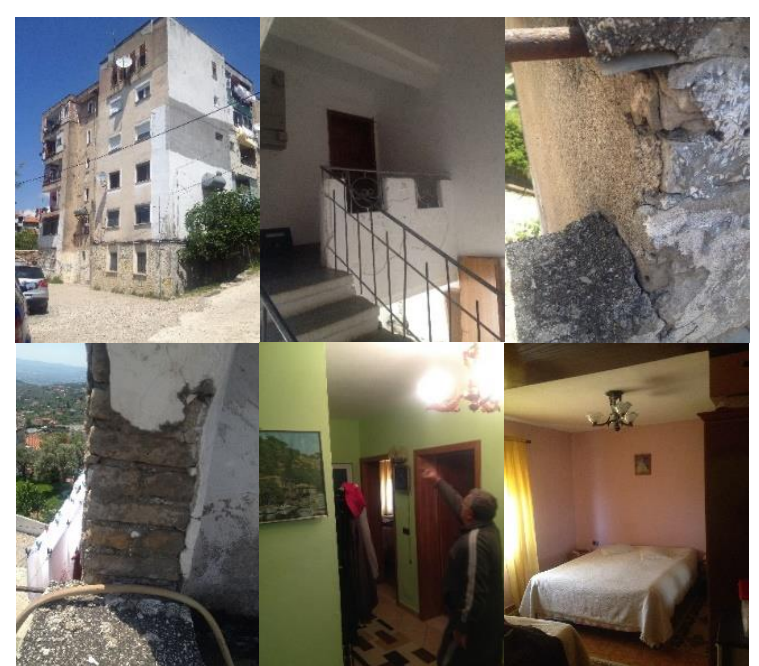

Fig. 6. A Photo of the socialist building; B.Atrium of the building; C.Masonry + outer plaster D.Masonry (silicate bricks) E; F. Indoor environment; Source: K.Xhexhi

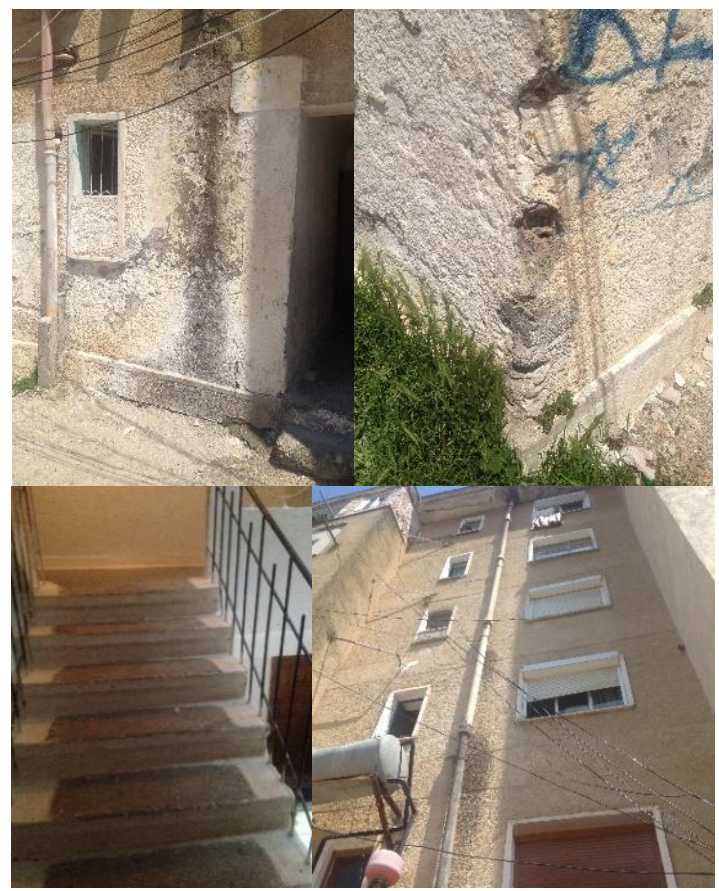

Fig. 7. A Relationship, ground floor-outside environment; B. Relationship, ground floor-outside environment; C.Staircase; D. Outer granular plaster Source: K.Xhexhi

These buildings (socialist ones) are raised from the ground with a few steps, which protects them from the moisture of the ground (Fig. 7a). Meanwhile the ground floor of the historic buildings stands more or less in the same level as the outside ground and in some cases even submerged by a few centimeters. This fact is not in favor of the historic buildings, in accordance to the maximum level of moisture.

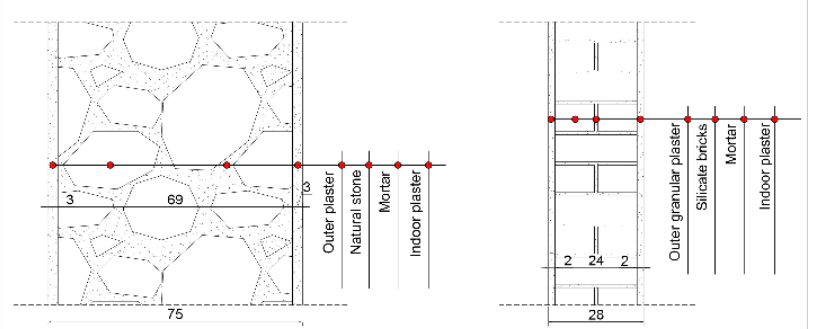

Fig. 8. A. Section of the typical outer wall (historic buildings); B. Section of the typical outer wall (socialist buildings)
TABLE I: AVERAGE VALUES OF OBSERVATIONS (MEASUREMENTS) FOR BOTH CATEGORIES

\begin{tabular}{|c|c|c|c|}
\hline \multicolumn{4}{|c|}{ "Average values of observation } \\
\hline \multicolumn{2}{|c|}{$\begin{array}{l}\text { Moisture content indoor walls } \\
+ \text { center of the floor }(\%)\end{array}$} & \multicolumn{2}{|c|}{$\begin{array}{l}\text { Indoor wall temperature +center of } \\
\text { the floor }\left({ }^{\circ} \mathrm{C}\right)\end{array}$} \\
\hline $\begin{array}{l}\text { Historic } \\
\text { buildings } \\
\text { number of } \\
\text { observations } 66\end{array}$ & $\begin{array}{l}\text { Socialist } \\
\text { buildings, } \\
\text { number of } \\
\text { observations } 55\end{array}$ & $\begin{array}{l}\text { Historic } \\
\text { buildings, } \\
\text { number of } \\
\text { observations } 66\end{array}$ & $\begin{array}{l}\text { Socialist } \\
\text { buildings, } \\
\text { number of } \\
\text { observations } 55\end{array}$ \\
\hline $21.21(\%)$ & $15.50(\%)$ & $9.09\left({ }^{\circ} \mathrm{C}\right)$ & $15.03\left({ }^{\circ} \mathrm{C}\right)$ \\
\hline \multicolumn{4}{|c|}{ Average values of observation } \\
\hline \multicolumn{2}{|c|}{ Facade temperature $\left({ }^{\circ} \mathrm{C}\right)$} & \multicolumn{2}{|c|}{ Indoor air temperature $\left({ }^{\circ} \mathrm{C}\right)$} \\
\hline $\begin{array}{l}\text { Historic } \\
\text { buildings, } \\
\text { number of } \\
\text { observations } 64\end{array}$ & $\begin{array}{l}\text { Socialist } \\
\text { buildings, } \\
\text { number of } \\
\text { observations } 37\end{array}$ & $\begin{array}{l}\text { Historic } \\
\text { buildings, } \\
\text { number of } \\
\text { observations } 24\end{array}$ & $\begin{array}{l}\text { Socialist } \\
\text { buildings, } \\
\text { number of } \\
\text { observations } 12\end{array}$ \\
\hline $7.03\left({ }^{\circ} \mathrm{C}\right)$ & $9.21\left({ }^{\circ} \mathrm{C}\right)$ & $16.58\left({ }^{\circ} \mathrm{C}\right)$ & $19.79\left({ }^{\circ} \mathrm{C}\right)$ \\
\hline
\end{tabular}

\section{B. Temperature}

Temperature is another important indicator in order to evaluate these two categories of dwellings. Three types of measurements have been done: facade temperature; the temperature of the interior walls, as well as the temperature of the air inside each room.

For historic buildings, the average temperature of the facade is $7.03^{\circ} \mathrm{C}$ from 64 measurements, the average interior wall temperature and the temperature in the center of the floor is $9.09^{\circ} \mathrm{C}$ from 66 measurements, and the average indoor air temperature is $16.58^{\circ} \mathrm{C}$ from 24 measurements. (It is important to note that at the time of measurement some of the windows were open).

For socialist buildings, the average temperature of the facade is $9.21^{\circ} \mathrm{C}$ out of 37 measurements, the average interior wall temperature and the center of the floor is $15.03^{\circ} \mathrm{C}$ from 55 measurements and the average indoor air temperature is $19.79^{\circ} \mathrm{C}$ from 12 measurements.

This paper will deal only with moisture content of the indoor walls + center of the floor and also with the indoor wall temperature + center of the floor temperature. The other parameters are just indicative (Table I).

It is noted that the temperatures of the historic buildings for the three measured parameters are relatively lower than in the case of the socialist buildings. This is justified by analyzing several elements:

1. The number of inhabitants per square meter. The socialist buildings, have a larger number of inhabitants per square meter, as a consequence all environments (rooms) are relatively livable, as a consequence will result a higher temperature for all three parameters. In historical dwellings this fact is important because residents prefer to concentrate mainly in the living room abandoning in some way other vital spaces, as a consequence will result lower temperatures in these spaces. They use the heating instruments only in the room where they spend most of their time.

2. Presence of thermal bridges. In most cases it turns out that the area of the roof of the historic dwelling as well as the area of windows and doors represent the biggest problem in terms of heat exchange coefficient. This fact is more highlighted in historical dwellings than in socialist ones. The historic dwellings have bigger problems with thermal bridges 
than the socialist ones thanks to weaker insulating materials such as windows, roof, doors.

The building envelope (foundations, roof, walls, windows, doors and floors) first of all provide shelter and protect the occupants from the outdoor environment creating a comfortable zone. In order to rich a high energy standard and a minimization of heat losses a sophisticated building envelope with a low U-value is required [22]. The building envelope is better isolated in the case of socialist buildings.

3. The economic aspect. Residents cannot afford the cost of renovating the problematic elements by replacing or improving them. The economic and actual physical situation of the historic dwellings seems to be poorer than the socialist ones.

4. Higher level of moisture content in the walls and floors of the historical dwellings.

It is noted that the facade temperatures are lower in the north-east and north-west orientation, and higher in the south-east and south-west respectively for both groups of buildings.

\section{METHODOLOGY}

In this paper it is going to be outlined the technique and analysis of linear regression models in estimating the relationship of moisture and temperature levels for the two dwelling typologies, historical and socialist ones. So the analysis will begin by finding the statistically significant relationships of the models:

$$
y=b 0+b 1 * x 1+b 2 * x 2+\ldots+b n * x n+\varepsilon
$$

It is noted:

$\mathrm{y}=$ dependent variable (In the study there is only one dependent variable for each housing typology, which is the level of moisture of the interior site of the wall and floor).

$\mathrm{xi}=$ independent variable for " $\mathrm{i}=1,2, \ldots, \mathrm{n}$ " and each of them is a vector with time values with periodicity year, (in this paper there is only one independent variable for each dwelling typology, which is temperature of the interior site of the wall and floor in degrees Celsus).

bi $=$ model parameters, or coefficients of the independent variables in the model, for " $\mathrm{i}=1,2, \ldots, \mathrm{n}$ " (in this regression analyze the dependent variable $\Delta y$ is explained related to these coefficients "bi", under "ceteris paribus".

$\varepsilon=$ is called the regression residual, or error term, is the only variable that is not predicted and should be stochastic.

The usual method of least squares [16] will be used for estimating "bi" parameters. In order to draw conclusions with high statistical reliability. Using a large number of observations, it is necessary to rely on all the basic assumptions of the theorem Gauss-Markov theorem [17]. According to this theorem several conditions must be met so that the mathematical regression model is the best and the most used one:

The first condition: the model must be linear or logarithmic in order to apply the method of least squares. Linearity should be given according to "bi" parameters.

The second condition: the model must have a single parameter b0 (called, the ordinate in the origin). This means that the mathematical expectation of the residuals is: " $\mathrm{E}(\varepsilon \mathrm{i})$
$=0 "$.

Third condition: the model must have the residual variance $\varepsilon$ constant, which means it should not have heteroscedasticity because the "bi" parameters are displaced, so it is statistically acceptable when they actually have to be rejected. This means that the residual variance is constant $\mathrm{V}(\varepsilon \mathrm{i})=\mathrm{E}(\varepsilon \mathrm{i} 2)=$ constant.

The fourth condition: the model should not be in terms of residual autocorrelation, i.e. the residual time evolution should be random and not explained by the preceding values, so the covariance $\operatorname{Cov}(\varepsilon i ; \varepsilon j)=0$ for each $\mathrm{i} \neq \mathrm{j}$.

Fifth condition: the model should not have multicollinearity, i.e. statistically significant correlation between the independent variables xi between them, or the variables and residuals $\varepsilon i$ of the model, for each $i=1,2, \ldots$, n.

By satisfying all these conditions, the model is stripped of all its unavoidable deviations and coincidences, making the ordinary least squares method the best explanatory and interpretive technique, i.e. minimizing any error term:

$$
\begin{aligned}
& \min \left\{\sum_{i}^{n}\left(y_{i}-\hat{y}_{i}\right)^{2}\right\}=\min \left\{\sum_{i}^{n}\left(\varepsilon_{i}\right)^{2}\right\} \\
& \text { for observations } i=1,2, \ldots, n
\end{aligned}
$$

With "yi" is noted as the measured value of the dwelling of the dependent variable (moisture) and with " $\hat{y}_{i}$ " is noted as the value obtained by the " $y$ " variable from the regression (model).

The statistical significance and model estimations will be analyzed by t-test and F-test with an error level with a probability of $5 \%$ or less, according to the most accepted standards of scientific statistical estimations.

\section{LINEAR MODEL FOR HISTORIC DWELLINGS}

According to the statistical testing process in the Eviews 8 program, the following statistical result of model parameter measurement is obtained:

$$
\begin{aligned}
& \text { Dependent Variable: Moisture } \\
& \text { Method: Least Squares } \\
& \text { Sample: } 166 \\
& \text { Included observations: } 66
\end{aligned}
$$

TABLE II: WORKED ON EVIEWS 8 BY THE AUTHOR (HISTORIC DWELLINGS)

\begin{tabular}{lllll}
\hline Variable & Coefficient & Std. Error & t-Statistic & Prob. \\
\hline $\mathrm{C}$ & 41.23063 & 9.711870 & 4.245385 & 0.0001 \\
\hline Temp. & -2.201669 & 1.045839 & -2.105170 & 0.0392 \\
\hline R-squared & 0.064761 & Mean dependent var & 21.21212 \\
\hline $\begin{array}{l}\text { Adjusted } \\
\text { R-squared }\end{array}$ & 0.050148 & S.D. dependent var & 16.45181 \\
\hline $\begin{array}{l}\text { S.E. of } \\
\text { regression }\end{array}$ & 16.03399 & Akaike info criterion & 8.417133 \\
\hline $\begin{array}{l}\text { Sum } \\
\text { squared }\end{array}$ & & & \\
resid. & 16453.68 & Schwarz criterion & 8.483486 \\
\hline $\begin{array}{l}\text { Log } \\
\text { likelihood }\end{array}$ & -275.7654 & Hannan-Quinn criter. & 8.443352 \\
\hline F-statistic & 4.431739 & Durbin-Watson stat & 1.824789 \\
\hline $\begin{array}{l}\text { Prob. } \\
\text { (F-statistic) }\end{array}$ & 0.039207 & & \\
\hline \hline
\end{tabular}

Related to the 66 measurements made in different points of the internal wall of historical dwellings, the relationship of moisture with temperature resulted as follow: 


$$
\text { Moisture }=41.23-2.2 * \text { Temperature }+\varepsilon
$$

As shown by the t-test and the F-test the statistical significance is very high and within the level of scientific acceptance (error rate less than 5\%). So the model is statistically significant. The level of moisture content of the wall surface is inversely related to the temperature of the same wall surface. If the temperature rises by 1 degree Celsius the moisture level will decrease by $2.2 \%$.

In the study of Seong Jin Chang and Sumin Kim, is investigated the hygrothermal performance of wooden building components and concrete wall structures mainly used in Korea. The study also verifies the level of humidity at different construction layers, the risk of condensation and the risk of mold growth. This article directly analyzes the correlation between temperature and moisture of the wall for both wall typologies (wood frame wall and concrete wall) The observation period was 3years. Moisture accumulation within the various wall system components depends to a great extent on the temperature profile across the different components. It is observed that lower indoor temperature results in higher moisture accumulation. Reducing the indoor air temperature results in lowering the temperature profile and consequently is expected a potential increase of moisture accumulation [12].

Related to the issue in another study is confirmed that increasing the moisture content of a $20 \mathrm{~cm}$ brick wall from $5 \%$ to $13 \%$ leads to reduce the thermal resistance by $25 \%$. Meanwhile increasing the moisture in a $20 \mathrm{~cm}$ concrete wall from $3 \%$ to $5 \%$ leads in reducing the thermal resistance by $20 \%$ [3].

Graphically, the distribution of the 66 measured values and regression line (estimated model) as well as the histogram of measurements in dwellings is:

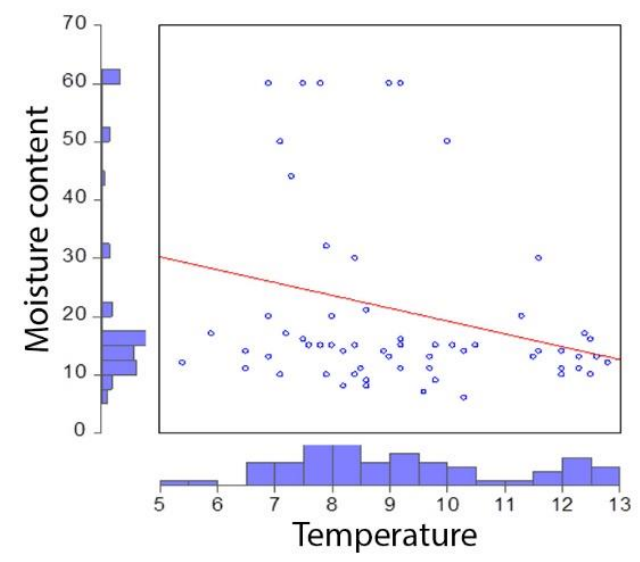

Fig. 9. Temperature-moisture graph for historical buildings.

$$
\text { Source: author }
$$

\section{LINEAR MODEL FOR SOCIALIST APARTMENTS}

According to the statistical testing process in the Eviews 8 program, the following statistical result of model parameter measurement is obtained:

Dependent Variable: Moisture

Method: Least Squares

Sample: 155

Included observations: 55
TABLE III. WORKED ON EVIEWS 8 BY THE AUTHOR

\begin{tabular}{|c|c|c|c|c|}
\hline Variable & Coefficient & Std. Error & t-Statistic & Prob. \\
\hline $\mathrm{C}$ & 29.84206 & 5.946741 & 5.018222 & 0.0000 \\
\hline Temp. & -1.017310 & 0.417640 & -2.435856 & 0.0183 \\
\hline R-squared & 0.100680 & \multicolumn{2}{|c|}{ Mean dependent var } & 15.50909 \\
\hline $\begin{array}{l}\text { Adjusted } \\
\text { R-squared }\end{array}$ & 0.083711 & \multicolumn{2}{|c|}{ S.D. dependent var } & 6.666313 \\
\hline $\begin{array}{l}\text { S.E. of } \\
\text { regression }\end{array}$ & 6.381193 & \multicolumn{2}{|c|}{ Akaike info criterion } & 6.580273 \\
\hline $\begin{array}{l}\text { Sum } \\
\text { squared } \\
\text { resid. }\end{array}$ & 2158.140 & Schwarz c & rion & 6.653267 \\
\hline $\begin{array}{l}\text { Log } \\
\text { likelihood }\end{array}$ & -178.9575 & \multicolumn{2}{|c|}{ Hannan-Quinn criter. } & 6.608500 \\
\hline F-statistic & 5.933395 & \multicolumn{2}{|c|}{ Durbin-Watson stat } & 1.420567 \\
\hline $\begin{array}{l}\text { Prob. } \\
\text { (F-statistic) }\end{array}$ & 0.018252 & & & \\
\hline
\end{tabular}
(SOCIALIST APARTMENTS)

Related to the 55 measurements made in different points of the internal wall of socialist apartments, the relationship of moisture with temperature resulted as follow:

$$
\text { Moisture }=29.84-1.02 * \text { Temperature }+\varepsilon
$$

As shown by the t-test and the F-test the statistical significance is very high and within the level of scientific acceptance (error rate less than 5\%). So the model is statistically significant. The level of moisture content of the wall surface is inversely related to the temperature of the same wall surface. If the temperature rises by 1 degree Celsius the moisture level will decrease by $1.02 \%$.

Graphically, the distribution of the 55 measured values and regression line (estimated model) as well as the histogram of measurements in dwellings is:

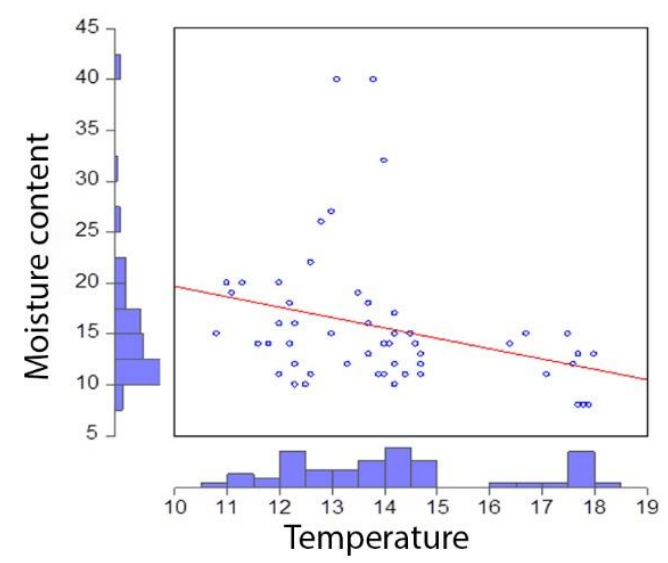

Fig. 10. Temperature-moisture graph for socialist buildings. Source: author

\section{CONCLUSIONS}

The historical and socialist dwellings in the city of Kruja suffer from lack of insulation and waterproofing protection. This is the main reason why moisture content in the masonry is relatively high for both categories. Historical dwellings have a lower number of inhabitance per square meter, have bigger problems with thermal bridges and a lower economic level than socialist dwellings. Their construction characteristics and building materials are totally different. 
The relation of moisture content to temperature through correlation of linear regressions for historical buildings turns out to be stronger than socialist buildings. Increasing the temperature by one degree, the moisture content will decrease by $2.2 \%$ for historic buildings and $1.02 \%$ for socialist buildings. The degree of reactivity is different for both groups of buildings. This indicates that historic buildings are more sensitive to temperature rise. They respond with a higher index and appear to be more effective in reducing wall moisture, despite the average moisture content is higher on these walls and floors. This reaction is directly related to the organic composition (building materials), thickness, moisture retaining ability of the wall and floor and the current level of moisture in it. Based on this parameter, historical buildings can be brought into the comfort zone more quickly than socialist ones as long as the inverse response coefficient is higher. Physical properties are strongly affected by moisture content. High moisture content for a long period of time may progressively degrade the building materials.

Knowing the moisture content in the interior walls and floor is important to determine also the appropriate measures to be taken to improve it.

By reducing the moisture on the masonry and on the floor, it is possible to make a significant improve in the living conditions of the inhabitants of Kruja, for both categories of building.

\section{REFERENCES}

[1] Karagiozis, A. and Salonvaara, M.2001, Building and Environment, Vol. 36(6), pp. 779-787 Moisture control; Moisture engineering, Building envelope modeling; Whole building performance; Aerated concrete.

[2] Moisture Control Guidance for Building Design, Construction and Maintenance U.S. Environmental Protection Agency December 2013.

[3] Mohamad KHARSEH, York OSTERMEYER, Claudio NÄGELI, Izabela KURKOWSKA, Holger WALLBAUM; "Humid Wall: Review on Causes and Solutions"; World Sustainable Built Environment Conference 2017 Hong Kong; Track 2: Practices \& Policies for High-Performance Buildings.

[4] J.L Miranda Dias, "Movement in Masonry Walls Caused by Temperature and Moisture Changes"; LNEC (National civil Engineering Laboratory)-Portugal

[5] Huibo Z, Hiroshi Y, Analysis of indoor humidity environment in Chinese residential buildings. Building Environment 45 (2010) 2132 2140.
[6] Kunzel H. M, "Hygrothermal behavior and simulation in buildings" 2010.

[7] Fang L, Clausen G, Fanger P.O, "The impact of temperature and humidity on perception of indoor air quality" Indoor Air 8(2) (1998) 80-90.

[8] Bornehag C.G, Sundell J, Bonini S, Custovic A, Malmberg P, Skerfving S. Sigsgaard T, Verhoeff A, "Dampness in buildings as a risk factor for health effects, EUROEXPO: a multi-disciplinary review of the literature (1998-2000) on dampness and mite exposure in buildings and heal the effects" Indoor Air 14(4) (2004) 243-57.

[9] Wang, F.; Yoshida, H.; Kitagawa, H.; Matsumoto, K.; Goto, K, "Model-based commissioning for filters in room air-conditioners" Energy Build. 2005, 37, 1225-1233.

[10] Dinh-Hieu V, Kuen-Sheng W, Bui H.B, Bui X.N, "Humidity control materials prepared from diatomite and volcanic ash", Construction and Building Materials 38 (2013) 1066-1072.

[11] Lucas, F.; Adelard, L.; Garde, F.; Boyer, H, "Study of moisture in buildings for hot humid climates", EnergyBuild. 2002, 34, 345-355.

[12] Seong Jin Chang; Sumin Kim, "Hygrothermal performance of exterior wall structures using a heat, air and moisture modeling", 6th International Building Physics Conference, IBPC 2015; Energy Procedia 78 (2015) 3434 - 3439.

[13] Lee, D.; Lee, K.; Bae, H, "Characterization of indoor temperature and humidity in low-income residences over a year in Seoul, Korea", Asian J. Atmos. Environ. 2017, 11, 184-193.

[14] Lloyd, C.R.; Callau, M.F.; Bishop, T.; Smith, I.J, "The e_cacy of an energy e_cient upgrade programme in New Zealand", Energy Build. 2008, 40, 1228-1239.

[15] Mercer, J.B, "Cold-an underrated risk factor for health", Environ. Res. 2003, 92, 8-13.

[16] Christopher Dougherty (2007) Introduction to Econometrics. Third edition, Oxford press.

[17] Alexander Ludwig and Klaus Schmidt (2010). Gauss-Markov Loss Prediction in a Linear Model.

[18] Joseph Lstiburek; John Carmody, "Moisture central Handbook, Priciples and practices for residential and small commercial buildings". ISBN 0-471-31863-9

[19] Brian Ridout; Iain McCaig, "Measuring Moisture Content in Historic Building Materials" Research Report Series no. 43-2016; ISSN 2059-4453

[20] A Hola 2017, "Measuring of the moisture content in brick walls of historical buildings - the overview of methods" IOP Conf. Ser. Mater. Sci. Eng. 251 012067; DOI:10.1088/1757-899X/251/1/012067

[21] Institute of Culture Monuments "Gani Strazimiri", Tirana, Albania

[22] Johannes Persson; "Low energy buildings (Energy use, indoor climate and market diffusion)"; Doctoral theises in chemical engineering; Stockholm, Sweden 2014.

[23] Hassan Radhi; Steve Sharples, "Forcasting carbon emmision of UAE residential sector- a case study of Abu-Dhabi"; PLEA 2011-27-th Conference on Passive and Low Energy Architecture, Louvain-laNeuve, Belgium, 13-15 July 2011

[24] Madhavi Indraganti, “ Importance of occupant's addaptive behaviours for sustainable thermal confort in apartments in India"; PLEA 201127-th; Conference on Passive and Low Energy Architecture, Louvainla-Neuve, Belgium, 13-15 July 2011

[25] Baoqing Zhang, Zukang Lei, "Experimental study on water content detection of traditional masonry based on infrared thermal image"; 2017 IOP Conf. Ser.: Mater. Sci. Eng. 248012030. 